\title{
MANAJEMEN PENDIDIKAN BERBASIS SEKOLAH DI RUMAH TAHFIZH AR-RAUDHAH JAKARTA UTARA
}

\author{
Moch. Yasykur \\ STAI Al-Hidayah Bogor \\ e-mail: yasykurmuhammad@gmail.com
}

Received: 19-07-2018, Accepted: 25-07-2018, Published:30-07-2018

\begin{abstract}
Good management is necessary for the success of educational institutions, therefore educational institutions can run well in accordance with the vision and mission. People assume that the teaching materials in public schools, especially at the primary school level in Jakarta are too heavy, the results are less satisfactory to some parents. So some people choose to include their children in private educational institutions that offer education with Islamic-based homeschooling system such as Tahfizh Qur'an school. The Advantages of Tahfizh ar-Raudhah House: first, offer the competence of santri in the form of: memorize Qur'an, able to speak arabic, as well as various religious subjects which are supported by an equivalence diploma. The public interest is so high that the demand continues to grow. Second, although only standing but able to educate children memorize the Qur'an $1 / 2$ juz in a month. Third, make al-'Arabiyyah Baina Yadaik as a guide book in Arabic material, even though the book is usually used at the junior high school level and above. Rumah tahfizh ar Raudhah schools that implement the MBS system in the implementation of the educational process. This school has also done empowerment in management such as; curriculum and teaching, student, finance and financing, educational staff, and infrastructure. Supporting factors of education management in Tahfizh ar Raudhah House, North Jakarta, among others; strategic location, donor support, and educators who understand Arabic and experienced in their field.
\end{abstract}

\begin{abstract}
Abstrak
Manajemen yang baik sangatlah diperlukan demi keberhasilan lembaga pendidkan, karenanya lembaga pendidikan dapat berjalan dengan baik sesuai dengan visi dan misinya. Masyarakat beranggapan bahwa materi ajar yang di sekolah umum terutama pada tingkat sekolah dasar di Jakarta terlalu berat, hasilnya pun kurang memuaskan sebagian orangtua. Sehingga sebagian orang memilih untuk memasukan anaknya pada lembaga pendidikan swasta yang menawarkan pendidikan dengan sistem homeschooling berbasis Islam seperti sekolah Tahfizh AlQur'an. Keunggulan Rumah Tahfizh Ar-Raudhah: pertama, menawarkan kompetensi santri berupa: hafal Al-Qur'an, mampu berbahasa arab, serta berbagai materi pelajaran keagamaan yang ditopang dengan ijazah kesetaraan. Animo masyarakat pun tinggi sehingga peminat terus bertambah. Kedua, meski baru berdiri namun mampu mendidik anak-anak menghafal Al-Qur'an $1 / 2$ juz dalam sebulan. Ketiga, menjadikan al-'Arabiyyah Baina Yadaik sebagai buku panduan dalam materi bahasa Arab, padahal buku tersebut biasa digunakan pada tingkat sekolah menengah pertama keatas. Rumah tahfizh ar Raudhah sekolah yang menerapkan sistem MBS dalam pelaksanaan proses pendidikannya. Sekolah ini juga telah melakukan pemberdayaan dalam manajemen seperti; kurikulum dan pengajaran, kesiswaan, keuangan dan pembiayaan, tenaga kependidikan, serta sarana prasarana. Faktor pendukung manajemen pendidikan di Rumah Tahfizh ar Raudhah Jakarta Utara
\end{abstract}


antara lain; letak yang strategis, dukungan donator, serta tenaga pendidik yang memahami bahasa arab dan berpengalaman di bidangnya.

Keywords: school based management, tahfizhul Qur'an house

\section{PENDAHULUAN}

Islam merupakan agama yang sangat memperhatikan dan memprioritaskan pendidikan, ayat yang pertama kali turun adalah perintah untuk membaca, Allah S.W.T. berfirman dalam Surat Al-'Alaq Ayat satu yang artinya, "bacalah dengan (menyebut) nama tuhanmu yang menciptakan". Belajar tak lepas dari kata membaca Allah S.W.T. memerintahkan belajar sebelum mengajar dan beramal.

Manajemen sangat berpengaruh dalam sebuah lembaga pendidikan, sehingga lembaga pendidikan tersebut dapat berjalan dengan baik sesuai dengan visi dan misi lembaga. Sebagian masyarakat merasa bahwa materi pelajaran yang ada di sekolah umum terutama pada tingkat sekolah dasar di Jakarta terlalu berat, peserta didik hanya mengikuti saja kurikulum yang ada yang hasilnya sendiri kurang memuaskan. Banyak dari mereka memilih untuk memasukan anaknya pada lembaga pendidikan swasta yang menawarkan pendidikan dengan sistem homeschooling, yang berbasis Islam dan tahfizh Al-Qur'an.
Di kota Jakarta Utara terdapat salah satu lembaga pendidikan swasta tingkat sekolah dasar berbasis homeschooling, yakni Rumah Tahfizh ar-Raudhah Jakarta Utara, yang berada di Jl. Kebantenan 1 No.9a RT 10 RW 5 Semper Timur Cilincing Jakarta Utara 14030. Lembaga tersebut berdiri pada tanggal 14 Desember 2015. Rumah Tahfizh arRaudhah Jakarta Utara merupakan lembaga pendidikan swasta yang baru akan tetapi mampu menarik perhatian banyak orang. untuk memasukan anaknya pada lembaga ini. Penulis tertarik untuk menjadikan Rumah Tahfizh ini sebagai tempat penelitian adalah; pertama, Rumah Tahfizh arRaudhah menawarkan kompetensi santri berupa: hafal al-Qur'an, mampu berbahasa arab, serta berbagai materi pelajaran diniyah atau keagamaan yang ditopang dengan memiliki ijazah kesetaraan paket A. Hingga sekarang animo masyarakat cukup tinggi sehingga peminat dan pendaftar semakin hari terus bertambah. Kedua, meski baru berdiri namun lembaga ini mampu mendidik anak-anak menghafal Al-Qur'an $1 / 2$ juz dalam sebulan. Ketiga, 
Rumah Tahfizh ini menjadikan al'Arabiyyah Baina Yadaik sebagai buku panduan dalam materi bahas Arab, yang mana buku tersebut umumnya digunakan pada tingkat sekolah menengah pertama keatas.

Alasan di atas mendorong penulis untuk mengetahui lebih dalam bagaimana manajemen pendidikan yang terdapat di Rumah Tahfizh arRaudhah Jakarta Utara selain faktor pendukung serta penghambat dalam proses pelaksanaan manajemen pendidikan pada lembaga tersebut.

Berdasarkan latar belakang di atas, maka perumusan masalah penelitian ini yaitu; bagaimanakah pelaksanaan manajemen penddikan di Rumah Tahfizh ar-Raudhah Jakarta Utara? dan faktor-faktor apa yang mendukung dan menghambat manajemen pendidikan di Rumah Tahfizh ar-Raudhah Jakarta Utara?

Hasil penelitian diharapkan bermanfaat bagi pengembangan ilmu pengetahuan. Secara teoritik, menambah hazanah teoritik bagi pengemban disiplin ilmu manajemen pendidikan. Sedangkan manfaat praktis dapat memberikan sumbangan praktis bagi para pengelola sekolah dalam melaksanakan manajemen pendidikan, dan khususnya bagi pengelola Rumah Tahfizh ar-Raudhah Jakarta.
TINJAUAN PUSTAKA

Manajemen dalam bahasa inggris artinya to manage, yaitu mengatur atau mengelola (Malayu S.P.Hasibuan, 1996: 1 Dalam arti khusus bermakna memimpin dan kepemimpinan, yaitu kegiatan yang dilakukan untuk mengelola lembaga atau organisasi, yaitu memimpin dan menjalankan kepemimpinan dalam organisasi. Orang yang memimpin organsasi disebut manajer (Hikmat, 2009). Kepemimpinan adalah terjemahan dari leadership. Kata leadership diambil dari kata "to lead" yang artinya memimpin. Untuk kata pemimpin atau memimpin, di dalam literatur Islam digunakan sedikitnya empat istilah, antara lain yaitu; Imam, Wali atau Auliya, Ra'in. Imam adalah orang yang dimakmumi (dijadikan pemimpin) oleh orang lain (M.Hidayat Ginanjar, 2018: 9). Oleh karena itu, kepemimpinan yang baik sangat mutlak dibutuhkan oleh umat, dan tentunya pemimpin masa depan yang diharapkan tampil adalah pemimpin yang memiliki sifat-sifat atau karakter terpuji, yakni yang berpihak pada kebenaran, keadilan, memiliki sifat amanah, jujur, keteladan, kesederhanaan, kebesaran jiwa, pemaaf, dan lain-lainnya yang mementingkan kemaslahatan bagi 
umat manusia. Karenanya, pemimpin membutuhkan arahan (taujih) dan latihan sejak dini, bisa didapatkan dari orang tua, guru, keluarga, sekolah, dan lingkungan masyarakat (M.Hidayat Ginanjar, 2018: 3-4).

\section{Para pakar administrasi} pendidikan, seperti Sergiovanni, Burlingame, Coombs, dan Thurston (1987) mendenifisikan manajemen sebagai process of working with and through others to accomplish organizational goals efficienctly, yaitu proses kerja dengan dan melalui (mendayagunakan) orang lain untuk mencapai tujuan organisasi secara efisien (Ibrahim Bafadhal, 2009: 39). Selain itu, manusia memiliki sejumlah kemampuan yang dapat dikembangkan melalui pengalaman. Pengalaman itu terjadi karena interaksi manusia dengan lingkungannya, baik lingkungan fisik maupun lingkungan sosial manusia secara efisien dan efektif itulah yang disebut dengan pendidikan (Umar Tirtarahardja \& Drs, S.L. La Sulo, 2005: 163).

\section{Berbagai macam pengertian} pendidikan yang dikemukakan oleh para ahli, ada juga diantara mereka yang berpendapat bahwa pengertian pendidikan bisa dibagi menjadi dua bagian. Pertama, definisi maha luas, pendidikan adalah hidup. Pendidikan adalah segala pengalaman belajar yang berlangsung dalam segala lingkungan dan sepanjang hidup. Pendidikan adalah segala situasi hidup yang memepengaruhi pertumbuhan individu (Redja Mudjaharjo, 2006: 3). Kedua, definisi sempit pendidikan adalah sekolah. Pendidikan adalah pengajaran yang diselenggarakan di sekolah sebagai lembaga penddikan formal. Pendidikan adalah segala pengaruh yang diupayakan sekolah terhadap anak dan remaja yang dserahkan kepadanya agar mempunyai kemampuan yang sempurna dan kesadaran penuh terhadap hubunganhubungan dan tugas-tugas sosial mereka (Redja Mudjaharjo, 2006: 6)

Dalam pengertian yang sederhana dan umum makna pendidikan sebagai usaha manusia untuk menumbuhkan dan mengembangkan potensi-potensi pembawaan baik jasman maupun rohani sesuai dengan nila-nilai yang ada dalam masyarakat dan kebudayaan (Fuad Ihsan, 2008: 1-2).

Dengan demikian yang dimaksud dengan manajemen pendidikan adalah kegiatan yang dilakukan untuk mengelola lembaga atau organisasi untuk menumbuhkan dan mengembangkan potensi-potensi pembawaan baik jasman maupun 
rohani sesuai dengan nila-nilai yang ada dalam masyarakat dan kebudayaan.

\section{Dasar-Dasar Manajemen Pendidikan} Islam

Dasar manajemen pendidikan Islam secara garis besar ada tiga yaitu; (1) Al-Qur'an, (2) As-Sunnah serta (3) perundang-undangan yang berlaku di Indonesia. Urgensi tentang hal ini banyak Ayat-ayat Al-Qur'an yang bisa menjadi dasar tentang manajemen pendidikan Islam. Ayat-ayat tersebut bisa dipahami setelah diadakan penelaahan secara mendalam. Di antara ayat-ayat Al-Qur'an yang dapat dijadikan dasar manajemen pendidikan Islam adalah sebagai berikut:

$$
\begin{aligned}
& \text { وَمَا كَانَ المُؤوْنِنُونَ لِيَنْفِرُوا كَافَّةً }
\end{aligned}
$$

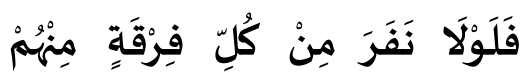

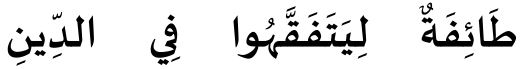

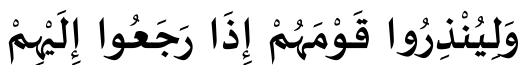

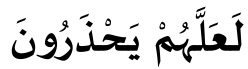

menjaga dirinya (QS. AtTaubah: 122).

Dengan demikian dapat disimpulkan bahwa Islam menegaskan tentang pentingnya manajemen, diantaranya manajemen pendidikan, lebih khusus lagi manajemen sumber daya manusia. Terkait hal ini, Rasulullah S.A.W. adalah juru didik dan beliau juga menjunjung tinggi terhadap pendidikan dan memotivasi umatnya agar berkiprah dalam pendidikan dan pengajaran. Rasulullah S.A.W. bersabda, "barang siapa yang menyembunyikan ilmunya maka Allah akan mengekangnya dengan kekang berapi". (HR. Ibnu Majah). Berdasarkan pada hadits di atas, Rasulullah S.A.W. memiliki perhatian yang besar terhadap pendidikan.

Dalam UU No. 20 Tahun 2003 tentang Sistem Pendidikan Nasional disebutkan dalam Pasal 30 ayat 1 bahwa: "Pendidikan keagamaan diselenggarakan oleh pemerintah dan/atau kelompok masyarakat dari pemeluk agama, sesuai dengan peraturan perundangundangan".

Disebutkan pula dalam pasal 30 ayat 2 bahwa "Pendidikan keagamaan berfungsi menyiapkan peserta didik menjadi anggota masyarakat yang memahami dan mengamalkan nilainilai ajaran agamanya dan/atau 
menjadi ahli ilmu agama" (Muhammad

Hakim Azhari, "Konsep Dasar Manajmen

Pendidikan",http://muhammadhakimaz

hari.blogspot.co.id/2014/04/konsep-

dasar-manajemen-pendidikan-

islam.html, pada tanggal 31 April 2018).

\section{Unsur Manajemen Pendidikan}

Dalam pengertian yang lebih luas, manajemen adalah suatu proses pengaturan, dan pemanfaatan sumber daya yang dimiliki organisasi melalui kerjasama para anggota untuk mencapai tujuan organisasi secara efektif dan efisien. Dalam perspektif ini ada sejumlah unsur pokok yang membentuk kegiatan manajemen, yaitu: unsure manusia (men), bahanbahan (materials), mesin (machines) metode (methods), uang (money) dan pasar (market). Keenam unsur ini memiliki fungsi masing-masing dan saling berinteraksi dalam mencapai tujuan organisasi terutama proses pencapain tujuan secara efektif dan efisien (Syafaruddin, 2005: 42-43).

Agar manajemen dapat berjalan dengan proses yang baik dan benar serta mencapai tujuan yang sebaikbaiknya, maka diperlukan adanya unsur-unsur manajemen. Karenanya untuk mencapai tujuan para manajer/pimpinan

biasanya menggunakan dengan istilah Enam $\mathrm{M}$ yang terdiri dari unsur-unsur manajemen diantaranya; (1) Man (Manusia), (2).Money (Uang), (3). Materials (Bahan), (4).Machines (Mesin), (5). Methods (Metode), (6). Markets (Pasar). Pasar merupakan salah satu sarana manajemen penting lainnya, khusus bagi perusahaanperusahaan atau badan yang bertujuan untuk mencari laba atau keuntungan. Karena pasar dipergunakan sebagai tempat pendistribusian barang-barang yang sudah dihasilkan (M.Manullang, 1996: 6). Kemudian, untuk menjamin keberhasilan sebuah usaha maka manajemen haruslah dilaksanakan berdasarkan prinsip-prinsip manajemen. Prinsip-prinsip manajemen adalah dasar-dasar dan nilai yang menjadi inti dari keberhasilan sebuah manajemen. Menurut Henry Fayol. Prinsip-prinsip dalam manajemen sebaiknya bersifat lentur dalam arti bahwa perlu dipertimbangkan sesuai dengan kondisi khusus dan situasi yang berubahrubah. Prinsip-prinsip umum manajemen menurut Henry Fayol terdiri dari; (1) Pembagian Kerja (Division Of Work), (2) Pemberian Wewenang dan Tanggung Jawab (Authority and Responsibility), 
Memiliki Disiplin (Discipline), (4) Adanya Kesatuan Komando atau perintah (Unity of command), (5) Adanya Kesatuan Arahan (Unity Of Direction), (6) Mengutamakan Kepentingan Organisasi diatas Kepentingan Sendiri, (7) Adanya Pemberian Kesejahteraan atau Gaju Pegawai, (8) Adanya Pemusatan Wewenang (Centralization), (9) Adanya Hirarki (Tingkatan) Pembagian Kerja, (10) Adanya Keadilan dan Kejujuran, (11) Adanya Stabilitas Kondisi Karyawan, (12) Adanya Prakarsa (Inisiative), (12) Semangat Kesatuan dan Semangat Korps.

\section{Komponen-Komponen Manajemen} Pendidikan

Dalam menunjang keberhasilan dari manajemen pendidikan diperlukan beberapa sumber daya dan komponenkomponen manajemen pendidikan. Komponen-komponen tersebut terdiri atas siswa, kurikulum, tenaga pendidik, sarana-prasarana, keuangan, lingkungan dan layanan khusus. Tujuh komponen ini saling bergantung satu sama lainnya. Komponen tersebut tidak dapat dipisah-pisahkan antara satu dengan yang lainnya dalam rangka mencapai tujuan yang telah ditetapkan sebelumnya. Komponen manajemen ini harus dilaksanakan secara serasi, menyeluruh,

berkesinambungan, karena antara komponen yang satu dengan lainnya saling mempengaruhi dan merupakan kesatuan untuk mencapai tujuan yang telah ditetapkan (Kartikha Eka Wardani, Mengenal Komponen-Komponen Manajemen Penddikan, http://kartikhaeka.blogspot.co.id/2016/1 2/mengenal-komponen-komponenmanajemen.html, pada tanggal 31 April 2018).

\section{METODOLOGI PENELITIAN}

Penelitian ini bertujuan untuk pelaksanaan manajemen pendidikan di Rumah Tahfizh ar-Raudhah Jakarta Utara dan faktor-faktor yang mendukung dan menghambat manajemen pendidikan di Rumah Tahfizh ar-Raudhah Jakarta Utara. Metode yang digunakan dalam penelitian ini adalah metode kualitatif, yaitu suatu proses penelitian dan pemahaman yang berdasarkan pada metodologi yang menyelidiki suatu fenomena sosial, peristiwa, perilaku alamiah orang-orang yang diamati dan menghasilkan data deskriptif berupa kata-kata tertulis ataupun lisan dari orang-orang tersebut. Pada pendekatan ini, peneliti membuat suatu gambaran yang kompleks dan menyeluruh, meneliti kata-kata, 
memberikan laporan terinci dari pandangan informan, dan melakukan studi pada situasi yang alami (Creswell, 1998:15).

Pendekatan yang digunakan berupa penelitian langsung mengamati objek yang dijadikan sasaran penelitian, yaitu proses dan pelaksanaan manajemen pendidikan di Rumah Tahfizh ar-Raudhah Jakarta Utara. Proses Penelitian ini meliputi beberapa fase yaitu (1) peneliti sebagai subjek, (2) paradigma dan sudut pandang teoritis, (3) strategi penelitian, yaitu studi kasus peranan rektor dalam membangun budaya kerja berbasis tauhid, (4) Metode Pengumpulan data dan analisis, melalui wawancara, observasi, artifak, dokumen, catatan, visual, pengalaman pribadi, pengolahan data, dan analisis tekstual, (5) Seni Interpretasi dan Penyajian, meliputi kriteria untuk menilai kecukupan, seni dan strategi interpretasi dan menulis sebagai interpretasi. (Norman K.Denzin dan Yvonna S.L, 2009: 16).

Lima komponen penting desain penelitian studi kasus yaitu pertanyaan-pertanyaan penelitian, (2) proposisi penyelidikan pada topik bahasan, (3) unit-unit analisis, (4) logika yang mengaitkan data dengan proposisi, (5) kriteria untuk menginterpretasi temuan. Pendekatan pertanyaan yaitu bagaimana dan mengapa (Robert. K. Yin, 2009: 27). Penelitian kualitatif dengan pendekatan alami menekankan pada peneliti sebagai instrument kunci dimana peneliti mengungkapkan kondisi yang dialami selama meneliti dengan sebenarnya, natural dan alami. Pengumpulan data dilakukan secara triangulasi (gabungan) dan analisis data bersifat induktif serta hasil penelitian lebih menekankan pada makna (Sugiyono, 2006: 8)

Waktu penelitian dilakukan pada bulan Januari sampai dengan bulan Juni 2018. Masa persiapan penelitian meliputi; observasi awal ke lokasi penelitian dan pengumpulan informasi terkait fokus masalah yang diteliti, selanjutnya mencari konsepkonsep terkait permasalahan penelitian melalui studi kepustakaan. Masa pelaksanaan meliputi; pengambilan data melalui kunjungan lokasi (grand tour observation) untuk mendapatkan gambaran umum konteks penelitian, wawancara dengan key informan dan informan. Menganalisis temuan dan menentukan fokus penelitian. Selanjutnya melakukan mini tour observation untuk menggali makna mendalam tentang fokus yang telah dipilih. Selanjutnya, melakukan pengolahan data hasil penelitian dan analisis melalui triangulasi data, akuntabilitas dan akseptabilitas, terakhir menyimpulkan hasil penelitian dan menuangkan dalam laporan.

\section{HASIL DAN PEMBAHASAN}

Rumah Tahfidz ar Raudhah Jakarta Utara berdiri di sebuah lembaga pendidikan yang berkonsentrasi pada pendidikan al Qur'an, yaitu Rumah Tahfizh ar Raudhah berdomisili di Jakarta Utara. Rumah Tahfizh ar Raudhah adalah 
lembaga pendidikan setingkat Sekolah Dasar, yang saat ini terus mengembangkan dan memajukan kualitasnya dalam mendidik para generasi Islam dengan menjadikan hafalan Al Qur'an sebagai orientasi pembelajaran setiap harinya. Rumah Tahfizh ar Raudhah Jakarta Utara berdiri pada tanggal 14 Desember 2015, pendiri sekaligus donatur tetap Rumah Tahfizh ar Raudhah, bekerjasama dengan beberapa asatidz untuk mendirikan Rumah Tahfizh ar Raudhah. (hasil wawancara dengan pendiri Rumah Tahfizh ar Raudhah pada tanggal 2 April 2018). Rumah Tahfizh ar Raudah Jakarta Utara saat ini telah mengalami pergantian kepala sekolah, pada tahun 2015 hingga 2016 dipimpin oleh Ustadz Ibnu Basyuni S.Pd. setelah itu dan hingga saat ini Rumah Tahfizh ar Raudhah dipimpin oleh Ustadz Eko Abu Ismail S.Pd. Rumah Tahfizh ar Raudhah masih dalam proses pengembangan, meski keterbatasan tempat yang saat ini belum memiliki gedung sendiri, dan masih bertempat di rumah donatur, minat murid baru sangat meningkat tiap harinya, hampir setiap hari ada calon murid yang hendak mendaftarkan diri bergabung di ar Raudhah, entah itu

kelas reguler pagi hari ataupun kelas TPA sore hari.

Rumah Tahfizh ar Raudhah Jakarta Utara tepatnya terletak di kawasan perumahan Dewa Kembar di Jl. Kebantenan 1 no.9a Rt 10 Rw 05, Semper Timur, Cilincing, Jakarta Utara dengan kode pos 14130. Akses transportasi menuju Rumah Tahfizh ar Raudhah sangat mudah, karena terletak di dekat Jl. Cilincing Raya dan jalan akses angkot KWK 05 dari arah Tanjung Priuk. Tranportasi menuju Rumah Tahfizh ar Raudhah sangatlah mudah karena berada di kota metropolitan Jakarta, banyak akses transportasi yang bisa di pilih seperti angkot, ojek online, taxi online, dan lain sebagainya. Hanya saja, akses transportasi menuju Rumah Tahfizh ar Raudhah Jakarta Utara tidak bisa langsung memakai busway, karena halte yang agak jauh dari letak Rumah Tahfizh ar Raudhah. (observasi, pada tgl 1 April 2018).

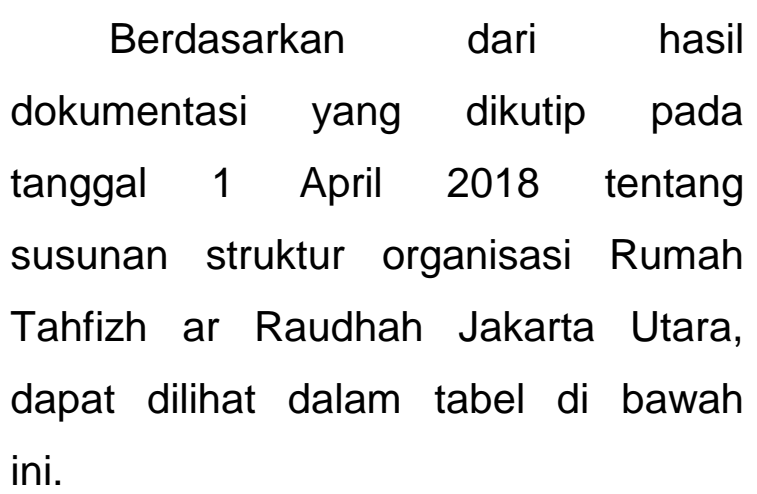


Susunan Pengurus Organisasi Rumah Tahfizh ar Raudhah Jakarta Utara

\begin{tabular}{|c|l|c|}
\hline No. & \multicolumn{1}{|c|}{ Nama } & Jabatan \\
\hline 1. & Asy'ari mahdi & Pengawas Yayasan \\
\hline 2. & Ridwan Wirabumi Asri,Lc & Pembina Yayasan \\
\hline 3. & Nashrudin Djaim & Pembina Yayasan \\
\hline 4. & Firman, SE & Pembina Yayasan \\
\hline 5. & Eko Hadiyanto, S.Pd.I & Ketua Pengurus Yayasan \\
\hline 6. & Adri & Wa.Ka Pengurus Yayasan \\
\hline 7. & Budiman & Sekertaris \\
\hline 8. & Alimin & Bendahara \\
\hline
\end{tabular}

(Dokumentasi, tanggal 9 April 2018)

Struktur Organisasi Rumah Tahfizh ar Raudhah Cilincing Jakarta Utara

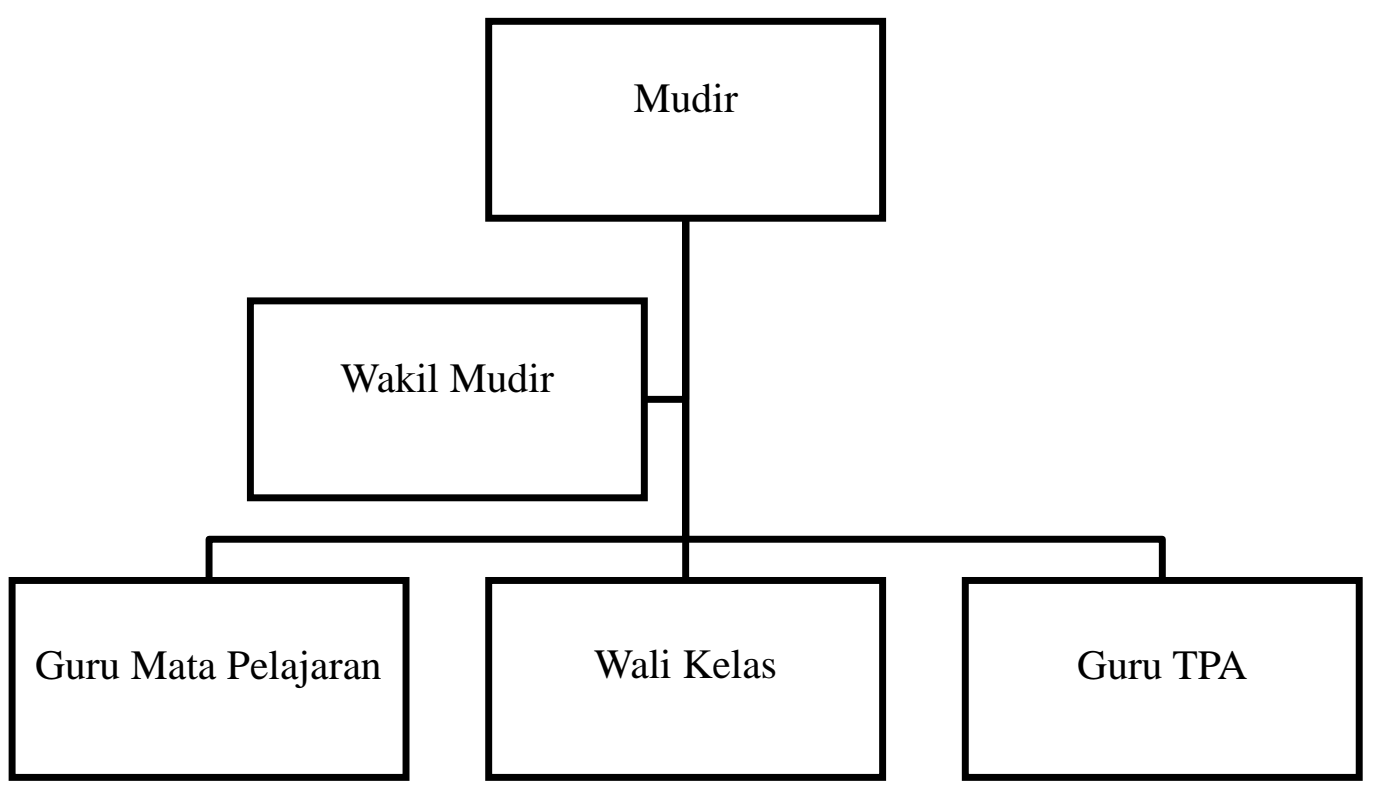

Keadaan Guru dan Siswa

Daftar Nama Guru Rumah Tahfizh ar Raudhah Jakarta Utara

\begin{tabular}{|c|l|c|l|c|c|}
\hline No. & \multicolumn{1}{|c|}{ Nama Guru } & L/P & \multicolumn{1}{|c|}{ Jabatan } & $\begin{array}{c}\text { Pendidikan } \\
\text { Terakhir }\end{array}$ & Lama Mengajar \\
\hline 1. & Eko Hidayanto, S.Pd.I & L & Mudir & & 9 Bulan \\
\hline 2. & Bambang, Lc & L & Wa.Ka Mudir & & 1 Tahun 4 Bulan \\
\hline 3. & Puspita Indah Fatmawati & P & Guru Kontrak & SMA-2013 & 1 Tahun 3 Bulan \\
\hline 4. & Ar Fadhilah Ilahi Dh & P & Guru Kontrak & SMA-2015 & 6 Bulan \\
\hline 5. & Nusaibah & P & Guru Kontrak & SMA-2015 & 5 Bulan \\
\hline 6. & Siti Maisitoh, .Ma.Pd & P & Guru Kontrak & & 4 Bulan \\
\hline
\end{tabular}

(Dokumentasi, tanggal 2 April 2018) 
Keadaan Siswa

Data Jumlah Siswa RT ar Raudhah Jakarta Utara

\begin{tabular}{|c|c|c|c|c|}
\hline \multirow{2}{*}{ No. } & \multirow{2}{*}{ Kelas } & \multicolumn{2}{|c|}{ Jenis Kelamin } & \multirow{2}{*}{ Jumlah } \\
\cline { 3 - 4 } & & Laki-laki & Perempuan & \\
\hline 1 & Pra Tahfizh & 6 & 3 & 9 \\
\hline 2 & Tahfizh Bantuan & 5 & 3 & 8 \\
\hline 3 & Tahfizh Mandiri & 1 & 8 & 9 \\
\hline \multicolumn{3}{|c|}{ Jumlah Siswa Keseluruhan } \\
\hline
\end{tabular}

(Dokumentasi, 9 April 2018)

Manajemen Pendidikan di Rumah Tahfizh ar Raudhah Jakarta Utara

Rumah Tahfizh ar Raudhah dalam menjalankan proses pendidikan mempunyai visi sebagai berikut: "Mencetak generasi qurani yang menghafalkannya, memahaminya, mengamalkannya, sampai mereka menggali potensi-potensi yang besar dari al-Qur'an secara mandiri” (Dokumentasi, 2 April 2018).

Rumah Tahfizh ar Raudhah dalam menjalankan proses pendidikan memiliki misi antara lain;

Membekali santri akidah salimah dan akhlak karimah, (2) Menerapkan pendidikan karakter qurani sejak dini, (3) Meningkatkan kualitas dan kuantitas hafalan al qur'an santri, (4) Membekali santri bahasa arab dasar, (5) Menumbuhkan kecintaan terhadap al qur'an dan bahasa arab sejak dini.

Tujuan didirikannya Rumah Tahfizh ar Raudhah Jakarta Utara adalah untuk, encetak para penghafal
Al-Qur'an sejak dini yang berakidah salimah, berakhlak karimah dan memahami bahasa arab dasar.

Berdasarkan observasi pada tanggal 20 April 2018 tentang aktivitas keagamaan di Rt ar Raudhah Jakarta Utara ditemukan beberapa aktivitas berikut; 1) Program Harian, meliputi; (1) Setoran hafalan setengah halaman setiap hari, (2) Shalat dhuha pada jam istirahat untuk membentuk pendidikan ruhiyah pada santri, (3) Shalat dzuhur berjama'ah wajib bagi santri sebelum pulang, (4) Muroja'ah hafalan setiap hari minimal 2 juz, (5) Santri diwajibkan mengucapkan salam setiap bertemu dengan guru dan teman atau masuk ruangan.

Selain aktivitas harian, RT ArRaudhah juga memiliki Program Mingguan, antara lain; (1) Mutqin sabaq 2,5 halaman, (2) Evaluasi tata tertib dan nasehat umum untuk para santri dan mudir, (3) Shalat jum'at untuk anak laki-laki di masjid dan 
membaca Alqur'an di kelas untuk anak perempuan, dilanjutkan shalat dzuhur bersama ustadzah, (4) Diwajibkan setiap siswa untuk mengisi kotak infaq yang dilaksanakan setiap hari jum'at, (5) Setoran hafalan wajib bagi guru pada hari rabu malam setelah isya.

Selain aktivitas harian dan mingguan, RT Ar-Raudah memiliki Program Bulanan dan Tahunan yang meliputi; (1) Hafalan mutqin 1 juz per 2 bulan, (2) Tasmi' hafalan anak-anak, (3) Pengumpulan hasil kuantitas dan kualitas hafalan santri kepada mudir. Hasilnya untuk mengetahui progress hafalan santri setiap bulan, Koordinasi/rapat bulanan yang diikuti oleh seluruh guru dan mudir sebaga koordinatornya. Adapun yang menjadi Program Tahunanannya yaitu; (1) Hafal mutqin 5 juz, dan (2) Rihlah ilmiah setelah ujian akhir semester ganjil.

\section{Manajemen Kurikulum dan Program Pengajaran}

Salah satu tugas kepala sekolah adalah mengelola kurikulum pengajaran bersama bagian kurikulum untuk tercapanya proses belajar mengajar yang baik. Rumah Tahfizh ar Raudhah Jakarta Utara ini merupakan sekolah swasta yang masih dalam pengembangan di bidang manajemennya, oleh karena itu dikarenakan tenaga kerja yang belum memadai, maka kepala sekolah yang bertanggung jawab dalam mengelola kurikulum pengajaran di Rumah Tahfizh ar Raudhah Jakarta Utara ini. Berdasarkan wawancara yang telah dilakukan pada tanggal 19 April 2018 dengan Ustadz Eko Hidayanto S.Pd.I selaku Kepala Sekolah dan merangkap menjadi Kabag. Kurikulum, diperoleh data bahwasanya Rumah Tahfizh ar Raudhah membuat kurikulum tersendiri atau pribadi yang merujuk pada konsentrasi tahfizh dan Al-Qur'an serta bahasa arab. Disamping itu, Rumah Tahfizh ar Raudhah juga memberikan pengajaran sesuai kurikulum Kemendikbud untuk matapelajaran yang diujikan pada Ujian Nasional, menggunakan buku panduan SPM Sekolah Dasar dan beberapa contoh soal-soal ujian nasional Sekolah Dasar.

Rumah Tahfizh ar Raudhah adalah sekolah tingkat Sekolah Dasar yang mempunyai visi, misi serta tujuan untuk membumikan keislaman pada masyarakat indonesia secara umum dan seluruh warga Rumah Tahfizh ar Raudhah secara khusus. Rumah Tahfizh ar Raudhah dengan segala kekurangan yang ada dan integritas yang ada menggunakan dan membuat kurikulum yang lebih memprioritaskan 
Al-Qur'an dan bahasa arab dasar, serta pendidikan agama Islam dan ibadah amaliyah. Rumah Tahfizh ar Raudhah juga memberikan pengajaran dengan membekali siswa beberapa mata pelajaran umum yang sifatnya sebagai suplemen tambahan.

Adapun pembagian tugas Utara.

mengajar, secara garis besar seluruh

\begin{tabular}{|c|l|r|l|l|}
\hline No & \multicolumn{1}{|c|}{ Nama Guru } & LP & \multicolumn{1}{|c|}{ Bidang Studi } & Asal Sekolah \\
\hline 1 & Eko Hidayanto S.Pd.I & L & Matematika & STITMAA \\
\hline & & & Bahasa Indinesia & \\
\hline & & & IPA & \\
\hline 2 & Puspita Indah Fatmawati & P & al Qur'an & MA Al Mukmin \\
\hline & & & Bahasa Arab & \\
\hline & & & Pend. Agama Islam & \\
\hline 3 & Nusaibah & P & al Qur'an & Ponpes. Annajiyah \\
\hline & & & Bahasa Arab & \\
\hline & & & Pend. Agama Islam & \\
\hline
\end{tabular}

Proses belajar mengajar yang berlangsung di Rumah Tahfizh ar Raudhah Jakarta Utara berlangsung selama empat jam empat puluh menit atau dimulai pukul 07:00-11:45 WIB. Khusus hari jum'at, proses belajar mengajar berlangsung selama kurang

Struktur Pengembangan Kurikulum Rumah Tahfizh ar Raudhah Jakarta Utara

\begin{tabular}{|l|c|c|c|c|c|c|}
\hline \multirow{2}{*}{ Mata Pelajaran } & \multicolumn{7}{|c|}{ Alokasi Waktu } \\
\cline { 2 - 7 } & I & II & III & IV & V & VI \\
\hline al Qur'an & 1020 & 1020 & 1020 & 1020 & 1020 & 1020 \\
\hline Bahasa Arab & 120 & 120 & 120 & 120 & 120 & 120 \\
\hline Pend. Islam & 30 & 30 & 30 & 30 & 30 & 30 \\
\hline Matematika & 60 & 60 & 60 & 20 & 20 & 20 \\
\hline Bahasa Indonesia & - & - & - & 20 & 20 & 20 \\
\hline IPA & - & - & - & 20 & 20 & 20 \\
\hline Jumlah & 1230 & 1230 & 1230 & 1230 & 1230 & 1230 \\
\hline
\end{tabular}

(Dokumentasi, 19 April 2018). 
Untuk mengawali pembelajaran di sekolah siswa membaca surat yang mendengarkan motivasi dari guru. Model pembelajaran yang dilakukan adalah dengan menggunakan model talaqqi kepada setiap guru mata pelajaran. Dengan model pembelajaran seperti ini diharapkan siswa dapat memahami dan menyerap pelajaran dengan lebih maksimal. Untuk menghindari kejenuhan, pengajar memberikan quality time kepada para siswa untuk menumbuhkan semangat belajar kembali seperti permainan yang bermanfaat dan berhubungan dengan pelajaran. Sebagai upaya untuk menciptakan sekolah yang efektif dan efisien, serta ideal maka sekolah mengusahakan ukuran kelas yang ideal dan eksklusif, yaitu satu kelas diisi dengan maksimal 10 anak. (Observasi, 19 April 2018).

\section{Manajemen Tenaga Kependidikan}

Manajemen tenaga kependidikan atau manajemen personalia pendidikan bertujuan untuk mendayagunakan tenaga kependidiakn secara efektif dan efisien untuk mencapai hasil yang optimal. Sehubunagn dengan itu, fungsi personalia yang harus dilakukan oleh pemimpin adalah mengatur, membimbing, mengembangkan, menggaji dan memotovasi personil akan dihafalkan pada hari itu juga,

guna mencapai tujuan sistem, membantu anggota mencapai posisi standar perilaku, memaksimalkan tenaga karir kependidikan, serta menyelaraskan tujuan individu dan organisasi. Rumah Tahfizh ar Raudhah Jakarta Utara dalam perekrutan tenaga kependidikan, memiliki standar tersendiri pada syarat juga ujian tes. Adapun syarat sebagai tenaga pendidik yaitu antara lain; 1) Bermanhaj ahlus sunnah wal jamaah, 2) Memiliki bacaan al Qur'an sesuai kaidah tajwid, 3) Minimal memiliki hafalan al qur'an 10 juz, hafal al qur'an lebih diutamakan, 4) Memiliki pengalaman mengajar anakanak., 5) Belum menikah.

Sistem perekrutan seperti di atas bertujuan agar diperoleh tenaga pendidik yang benar-benar mampu mengajar dan bekerjasama dengan Rumah Tahfizh ar Raudhah Jakarta Utara demi tercapainya visi, misi serta tujuan didirikannya Rumah Tahfizh ar Raudhah Jakarta Utara. Usaha- usaha yang dilakukan pihak sekolah dalam tangka pembinaan profesi tenaga kependdikan adalah dengan mengoptimalkan pembinaan secara efektif dan efisien, dengan ikatan kekeluargaan antara posisi dan peran pada masing-masing personil. Serta 
membantu dalam meningkatkkan kualitas tenaga kependidikan, dengan memfasilitasi serta membimbing para guru dalam meningkatkan kualitas dan kuantitas hafalan Al-Qur'an mereka.

Berkaitan dengan syarat profesional, Rumah Tahfizh ar Raudhah lebih memprioritaskan kemampuan hafalan al qur'an secara kualitas dan kuantitas, karena pada dasarnya tingkat pendidikan setingkat sekolah dasar ini mengedepankan binaan dan pengajaran Al-Qur'an kepada peserta didik, dengan tidak mengenyampingkan pendidikan dasar bahasa arab pada mereka. Setiap guru harus memiliki kemampuan dasar bahsa arab dan pendidikan agama islam yang mumpuni. Setiap tenaga kependidikan memegang satu kelas dan mengajarkan pelajaran Al-Qur'an, bahasa arab dasar, dan pendidikan agama islam.

Adapun untuk peningkatan kesejahteraan atau honorarium yang dipakai adalah sesuai dengan kebijakan yang telah ditentukan dari yayasan Ar raudhah sendiri. Rumah Tahfizh ar Raudhah menggunakan sistem kontrak kerja dalam merekrut tenaga kependidikan dengan minimal kerja enam bulan, pada awalnya. Akan tetapi, pada tahun ajaran 2018/2019 ini Rumah Tahfizh ar Raudhah memberlakukan peraturan baru dalam merekrut tenaga kependidikan dengan minimal kontrak kerja satu tahun pelajaran.

Guru baru wajib melalui proses percobaan mengajar atau magang minimal 2 hari. Setelah masa kontrak habis, jika diarasa guru tersebut layak untuk dipekerjakan kembali maka kontrak akan diperpanjang. Namun, jika pihak kedua meginginkan untuk tidak memperpanjang masa kontrak maka mereka diberi kebijakan dalam hal tersebut. (Wawancara dengan kepala sekolah, 14 April 2018).

\section{Manajemen Kesiswaan}

Manajemen kesiswaan bertujuan untuk mengatur berbagai kegiatan dalam bidang kesiswaan agar kegiatan pembelajaran di sekolah dapat berjalan lancar, efektif dan efisien, teratur serta tertib sehingga tercapa tujuan pendidikan sekolah. Untuk mewujudkan tujuan pendidikan sekolah bagaian manajemen kesiswaan yang mana sementara masih dipegang oleh mudir Rumah Tahfizh ar Raudhah ini setidaknya memiliki tiga tugas utama, yaitu penerimaan siswa baru, kegiatan kemajuan belajar, serta bimbingan dan pembinaan disiplin. Berdasarkan wawancara dengan Mudir atau Kepala 
Sekolah Rumah tahfizh ar Raudhah Jakarta Utara pada tanggal 14 April 2018, diperoleh data antara lain; 1) Penerimaan siswa baru (PSB). Kepala Sekolah membentuk kepanitiaan yang khusus bertanggung jawab terhadap PSB. Adapun dalam sosialisasi PSB dilakukan dengan berbagai cara, di antaranya adalah dengan memberikan informasi secara berantai dari semua warga sekolah, penyebaran soft brosur di media sosial, pemasangan spanduk serta mengikuti berbagai lomba tahfizh Al Qur'an, 2) Kegiatan kemajuan belajar serta bimbingan pembinaan disiplin. Dalam hal ini sekolah memberikan peran kepada setiap Wali Kelas untuk membimbing siswa agar potensi mereka berkembang optimal, yang selanjutnya diserahkan kepada Mudir jika dilihat perlu. Dikarenakan tenaga kependidikan yang masih dalam tahap perkembangan di Rumah Tahfizh ar Raudhah sementara ini belum ada BK (Bimbingan Konseling).

\section{Manajemen}

Keuangan

dan Pembiayaan

Keuangan dan pembiayaan merupakan sumber daya yang penting dalam menunjang perkembangan serta kelangsungan kegiatan pendidikan di sekolah, sehingga sekolah dituntut untuk merencanakan, melaksanakan, mengevaluasi

serta mempertanggungjawabkan pengelolaan secara transparan kepada masyarakat. Komponen keuangan ini perlu dikelola sebaik-baiknya agar tercapai tujuan pendidikan di sekolah secara efektif dan efisien.

Rumah Tahfizh ar Raudhah Jakarta Utara telah merencanakan sedemikian rupa dalam hal keuangan, mengingat Rumah Tahfizh ar Raudhah adalah sekolah swasta, maka keuangan merupakan hal vital dalam kelangsungan manajemen pendidikan di sekolah. Dalam hal ini Rumah Tahfizh ar Raudhah memiliki tiga tahapan dalam perencanaan anggaran serta manajemen keuangan di sekolah, yaitu; 1) Perencanaan keuangan, tugas dari perencanaan keuangan adalah mengkoordinasi sumber daya keuangan secara garis besar yang ada disekolah, bersumber dari tiga komponen: Yayasan ar Raudhah, donatur tetap serta orang tua siswa. Pembayaran infaq bulanan (SPP) siswa di Rumah Tahfizh ar Raudhah Jakarta Utara adalah sesuai kemampuan para siswa sendiri, dengan minimal pembayaran Rp.100.000, setiap siswa. Rumah Tahfizh ar Raudhah membebaskan biaya pendidikan kepada seluruh siswa angkatan pertama, 2) Implementasi 
keuangan, tugasnya adalah melaksanakan anggaran keuangan yang telah direncanakan sebelumnya dengan setelah disetujuinya rencana anggaran tersebut oleh pihak yayasan, 3) Evaluasi keuangan, tugasnya adalah membukukan semua pemasukan dan pengeluaran anggaran yang ada secara transparan dan sesuai dengan rencana dan implementasi anggaran keuangan sekolah, yang kemudian dilaporkan kepada pihak yayasan serta orang tua siswa. (Wawancara dengan Eko Hidayanto S.Pd.I (Kepala Sekolah) pada tanggal 19 April 2018).

\section{Manajemen Sarana dan Prasarana Pendidikan}

Manajemen sarana dan prasarana pendidikan bertugas mengatur perencanaan pengadaan sarana pendidikan, merawat serta menyimpan sarana prasarana yang ada sehingga membantu jalannya proses pendiidkan dengan efektif. Sementara ini, belum ada Kabag. Sarana dan Prasarana di Rumah Tahfizh ar Raudhah. Akan tetapi, bukan berarti tidak ada sarana prasarana yang memadai di sekolah ini. Bahkan secara global sarana prasarana di Rumah Tahfizh ar Raudhah sudah sangat terpenuhi dilihat dari garis besarnya dan pemasukan keuangan yang ada. Meski demikian, Rumah Tahfizh ar Raudhah masih dalam tahap perkembangan dilihat dari sisi sarana kelas dan sekolah yang masih menetap dirumah donatur.

\section{Faktor Pendukung dan Penghambat Manajemen Pendidikan di Rumah Tahfizh ar Raudhah Jakarta Utara}

Faktor pendukung manajemen pendidikan di Rumah Tahfizh ar Raduhah Jakarta Utara antara lain; 1) Fasilitas sekolah, meliputi; (1) Letak sekolah yang strategis, (2) Pelayanan yang tanggap dari donatur dalam memfasilitasi KBM. 2) Tenaga pendidik, meliputi; (1) Semua guru mempunyai hafalan al qur'an minimal 10 juz, (2) Semua guru memahami bahasa arab dasar dengan baik. 3) Kegiatan pembelajaran, meliputi; (1) Adanya jam pelajaran tambahan untuk pelajaran yang diujikan pada ujian nasional, (2) Setiap siswa mampu membaca al qur'an dengan baik dan benar, (3) Guru pelajaran al qur'an dan bahasa arab adalah mereka yang berpengalaman dalam bidangnya. 3) Kelembagaan, meliputi: (1) pengelolaan pendidikan dibawah naungan yayasan ar Raudhah Cilincing, (2) Dukungan positif dari para wali murid berkenaan dengan program sekolah, (3) Persamaan persepsi pada pihak guru tentang visi, misi dan tujuan sekolah. 
Adapun yang menjadi faktor penghambat manajemen pendidikan di Rumah Tahfizh ar Raudhah Jakarta Utara antara lain; 1) Belum memiliki gedung sekolah sendiri, 2) Kurangnya tenaga kependidikan, Keanekaragaman umur siwa dalam satu kelas. (wawancara dengan Kepala Sekolah, pada tanggal 19 April 2018).

\section{Pelaksanaan Manajemen Pendidikan di Rumah Tahfizh ar Raudhah}

Rumah Tahfizh ar Raudhah Jakarta Utara merupakan lembaga pendidikan setingkat Sekolah Dasar yang berlandaskan Islam. Manajemen pendidikan di Rumah Tahfizh ar Raudhah Jakarta Utara masih dalam tahap pembenahan dan peningkatan, akan tetapi selaras dengan berjalannya proses pengajaran di Rumah Tahfizh ar Raudhah Jakarta Utara, Kepala Sekolah beserta dewan guru selalu meningkatkan kinerja dan kualitas agar tercipta kegiatan pengajaran yang efektif dan efisien, mengarah pada sistem MBS (Manajemen Berbasis Sekolah), yang diiringi dengan kurikulum yang dibuat oleh pihak sekolah sendiri, mengingat tidak semua MBS mengarah pada pendidikan keislaman yang optimal.

\section{Manajemen Kurikulum dan Program Pengajaran}

Kurikulum merupakan perwujudan dari proses pendidikan secara global. Kurikulum seperti etalase yang menyempurnakan isi yang ada didalamnya, yaitu ini dari proses pendidikan di sekolah. Sebuah etalase yang terlihat rapi dan menarik akan memeberikan efek positif pada barang di dalamnya, begitu juga peranan kurikulum dalam proses pendidikan. Pada dasarnya kurikulum di Rumah Tahfizh ar Raudhah Jakarta Utara ini sudah direncanakan secara matang oleh tim pendiri serta tim pembimbing.

Mulanya, tim pendiri dan tim pembimbing hanya memprioritaskan pengajaran Al-Qur'an dan bahasa arab saja, dengan perbandingan $65 \%$ dan $35 \%$. Akan tetapi, sejalan dengan kegiatan belajar mengajar yang ada saat ini, Rumah Tahfizh ar Raudhah Jakarta Utara menerapkan kurikulum tambahan berupa pengajaran pelajaran yang berkaitan dengan ujian nasional tingkat SD seperti Matematika, Bahasa Indonesia, dan IPA. Dengan demikian, bisa dikatakan bahwa Rumah Tahfizh ar Raudhah Jakarta Utara masih sangat butuh kerja keras untuk meningkatkan sistem pengajaran dan kurikulum agar jalannya proses pendidikan menjadi lebih optimal 
sesuai dengan visi, misi dan tujuan sekolah.

\section{Manajemen Tenaga Kependidikan}

Berdasarkan teori manajemen yang telah penulis paparkan pada bab II serta pemaparan pola manajemen tenaga kependidikan di Rumah Tahfizh ar Raudhah Jakarta Utara pada bab III, maka penulis dapat mengatakan bahwa tenaga kependidikan di Rumah Tahfizh ar Raudhah Jakarta Utara masih sangat minim dan perlu increasing. Dapat dilihat dari tabel dan struktur organisasi yang mana personil masih ada yang merangkap posisi dan peran dalam kegiatan manajerial.

Manajemen tenaga kependidikan sangat menentukan kualitas tenaga kependidikan yang akan terjun dalam proses pendidikan di sekolah, tenaga kependidikan merupakan bagian yang sangat vital dan bisa menjadi vatal jika dalam perekrutannya tidak sejalan dengan persyaratan tenaga kependidikan yang ditentukan, adapun syarat-syarat tenaga kependidikan di Rumah Tahfizh ar Raudhah antara lain; 1) Bermanhaj ahlus sunnah wal jamaah, 2) Memiliki bacaan al qur'an sesuai kaidah tajwid, 3) Minimal memiliki hafalan al qur'an 10 juz, hafal al qur'an lebih diutamakan, 4) Memiliki pengalaman dan senang mengajar anak-anak, 5) Belum menikah.

Dalam perekrutan tenaga kependidikan, manajemen tenaga kependidikan yang diterapkan sangat ketat dalam mengevaluasi hasil perekrutan tenaga kependidikan, agar mendapat hasil yang maksimal serta memudahkan proses jalannya kegiatan belajar mengajar dan proses pendidikan d sekolah secra efektif dan efisien.

Honorarium yang diterapkan di Rumah Tahfizh ar Raudhah untuk tenaga kependidikan sudah ditentukan secara rinci dan kualifikatif sesuai dengan yayasan yang ada. Dengan demikian, penulis dapat menyimpulkan bahwa Rumah Tahfizh ar-Raudhah Jakarta Utara ini telah menyelenggarakan kegiatan mengajar, mengembangkan, mengelola, dan memberikan pelayanan teknis dalam bidang pendidikan, sesuai dengan teori yang telah penulis paparkan pada bab II.

\section{Manajemen Kesiswaan}

Manajemen kesiswaan merupakan bagian yang penting dalam membantu disiplin siswa dan pembimbingan serta pengaturan agar tercipta kegiatan belajar mengajar secara tertib, teratur dan terlaksana sesuai dengan tujuan sekolah. Bidang manajemen kesiswan 
bertugas mengatur segala bidang kesiswaan di sekolah. Perencanaan secara optimal dan pelaksanaan yang selaras yang diharapkan dari bidang manajemen kesiswaan sendiri.

Dalam masalah PSB, Rumah Tahfizh ar Raudhah terlihat sudah sangat baik dalam pelaksanannya. Terlihat dari proses pembukaan pendaftaran siswa baru yang dilaksanakan sekitar enam bulan sebelum tahun ajaran baru dimulai. Promosi dan selebaran soft brosur telah disebarkan secara insidental dan radiosasi seluruh warga Rumah Tahfizh ar Raudhah Jakarta Utara baik melalui media sosial dan ikut serta dalam beberapa lomba.

Selain mengelola PSB, bagian manajemen kesiswaan juga menghandle masalah bimbingan konseling serta kegiatan kesiswaan yang ada di rumah tahfizh ar Raudhah. Seperti yang telah dipaparkan penulis tentang manajemen kesiswaan di Rumah Tahfizh ar Raudhah Jakarta Utara bahwa untuk kabag. Kesiswaan belum dihandle secara khusus akan tetapi masih dijalankan dan diperankan bersama yang mana Kepala Sekolah disisni bertugas mengkoordinir para guru.

Dengan demikian, dapat disimpulkan bahwa Rumah Tahfizh ar
Raudhah sudah menjalankan tugas manajerial di bidang kesiswaan dengan baik, sehingga tercapailah tujuan sekolah dengan tertib dan teratur.

\section{Manajemen Keuangan dan Pembiayaan}

Rumah Tahfizh ar Raudhah merupakan lembaga pendidikan dengan sistem MBS (Manajemen Berbasis Sekolah). Secara garis besar pokok pembiayaan yang ada di sekolah ini terdapat dari dua sumber: pertama, yaitu donatur Rumah Tahfizh ar Raudhah dan orang tua murid. Kedua, adalah dari para muhsinin.

Sekolah ini melaksanakan manajerial keuangan dalam tiga fase, yaitu: merencanakan, melaksanakan dan mengevaluasi. Dengan tiga fase tersebut sekolah ini dapat melaporkan semua aktifitas keuangan kepada yayasan, donatur, masyarakat dan pemerintah secara transparan. Selain hal tersebut, Rumah Tahfizh ar Raudhah Jakarta Utara melaksanakn manajerial keuangan dengan sangat optimal untuk memenuhi segala kepentingan dan keperluan proses pendidikan di sekolah ini, dengan pengawalan ketat dan Kepala Sekolah sebagai koordinator maka pelaksanaannya bisa berjalan dengan mudah. 
Dengan demikian, setelah penulis paparkan tentang teori manajemen keuangan dan pembiayaan pada bab II dan pemaparan penulis tentang manaerial keuangan pada bab III ini, dapat disimpulkan bahwa Rumah Tahfizh ar Raudhah Jakarta Utara ini sudah sangat baik dalam pelaksanaan manajerial keuangan dan pembiayaan, meski terhitung sekolah ini adalah sekolah yang baru didirikan.

\section{Manajemen Sarana dan Prasarana Pendidikan}

Rumah tahfizh ar Raudhah Jakarta Utara sebagai sekolah yang masih berbau kencur (masih baru) memang belum mempunyai sarana dan prasarana secara optimal, seperti gedung sekolah yang masih meminjam kepada donatur. Akan tetapi secara global sarana dan prasarana di sekolah ini sudah cukup memadai dan memfasilitasi sesuai kebutuhan proses pendidikan yang berjalan sekarang tanpa ada hambatan.

Penyelenggaraan sarana dan prasarana di rumah Tahfizh ar Raudhah berjalan secara tanggap dan cepat, apabila ada barang sekolah yang kurang ataupun rusak, maka pihak sekolah langsung mengganti dan atau membelinya dengan yang baru tanpa menunggu waktu yang lama.
Sehingga proses pendidikan di sekolah ini berjalan dengan efektif.

\section{KESIMPULAN}

Berdasarkan pemaparan penulis pada bab-bab sebelumnya maka dapat disimpulkan antara lain; bahwa Rumah Tahfizh ar-Raudhah, merupakan sekolah swasta yang menerapkan sistem MBS dalam pelaksanaan proses pendidikannya. Sekolah ini juga telah melakukan pemberdayaan dalam bebrapa manajemen di sekolah seperti; kurikulum dan pengajaran, kesiswaan, keuangan dan pembiayaan, tenaga kependidikan, dan sarana prasarana.

Rumah Tahfizh ar-Raudhah Jakarta Utara menerapkan sistem kurikulum Qur'ani yang menargetkan siswa menjadi generasi rabbani yang menghafal Al-Qur'an dan mengamalkannya.

Faktor pendukung manajemen pendidikan di Rumah Tahfizh arRaudhah Jakarta Utara yaitu; (1) letak yang strategis, donatur yang tanggap dalam masalah keuangan, (2) para guru yang memiliki hafalan minimal 10 juz, (3) semua guru memahami bahasa arab dasar dengan baik, dan para guru yang mengajar adalah para guru yang berpengalam dibidangnya.

Adapun faktor penghambat manajemen pendidikan di sekolah ini 
antara lain; (1) sekolah tahfizh belum memiliki gedung sendiri, (2) kurangnya jumlah tenaga pendidik dan kependidikan.

\section{DAFTAR PUSTAKA}

Al-Maraghi, Ahmad Mustafa. (1993). Tafsir Al-Maraghi Juz XV. Semarang: PT. Karya Thoha Putra.

Ahmadi, lif Khoiru dan Sofan Amri.

(2011). PAIKEM Gembrot. Jakarta:

PT Prestasi Pustakaraya

Arifin, Muhammad (1996). IImu

Pendidikan Islam. Jakarta: Bumi Aksara.

Amanah. (1991). Pengantar IImu Al-

Qur'an dan Tafsir. Semarang: Asy-Syifa

Bungin, Burhan. (2007). Penelitian

Kualitatif. Jakarta: Kencana

Prenada Media Grup.

Burhanudin dan Esa Nur Wahyuni.

(2010). Teori Belajar dan

Pembelajaran. Yogyakarta: Ruzz

Media.

Dakir. (2004). Perencanaan dan

Pengembangan

Kurikulum.

Jakarta: PT. Asdi Mahasatya.

Dimyati dan Mudjiono. (2006). Belajar

dan Pembelajaran. Jakarta: PT.

Rineka Cipta.

Departemen Pendidikan dan

Kebudayaan. (1995). Kamus
Besar Bahasa Indonesia. Jakarta: Balai Pustaka.

Djamarah, Saipul Bahri, (2002).

Strategi Belajar Mengajar. Jakarta:

PT. Rineka Cipta.

Eriyanto. (2011). Analisis Isi: Pengantar

Metodologi Untuk Penelitian IImu Komunikasi dan IImu Sosial Lainnya. Jakarta: Kencana.

Ginanjar

M. H.

(2018).

KARAKTERISTIK

KEPEMIMPINAN PENDIDIKAN

ISLAM

BERBASIS

MASJID. Islamic Management:

Jurnal Manajemen Pendidikan Islam, 1(01).

Ginanjar, M. H. (2017). MEMBANGUN BUDAYA KERJA SYARIAH DALAM UPAYA MENINGKATKAN KUALITAS KINERJA DOSEN (PENELITIAN DI UNIVERSITAS DJUANDA BOGOR). Edukasi Islami: Jurnal Pendidikan Islam, 3 (06).

Hamalik. (2001). Kurikulum dan

Pembelajaran. Jakarta: Bina Aksara.

Humam, As'ad. (1990). Buku lqra' Klasikal. Yogyakarta: Balai Litbang LPTQ Nasional Team Tadarus "AMM".

Jogiyanto. (2006). Pembelajaran Metode Kasus. Yogyakarta: Andi Offset. 
Kurnaedi, Abu Ya'la. (2010). Metode Asy-Syafi'i:Ilmu Tajwid Praktis.

Jakarta: Pustaka Imam Asy-Syafi'i. Moleong, Lexy J, (2013). Metode Penelitian Kualitatif. Bandung: PT. Remaja Rosdakarya.

M. Dalyono. (2010). Psikologi Pendidikan. Jakarta: PT. Rineka Cipta.

Max Darsono. (2001). Belajar dan Pembelajaran. Semarang: IKIP PGRI.

Muhaimin. (2008). Kontroversi

Pemikiran Fazlur Rahman Studi Kritis Pembaharuan Pendidikan Islam. Jakarta: Pustaka Dinamika. Mukhtar. (2007). Bimbingan Skripsi,

Tesis, dan Karya IImiah. Jakarta:

Gunung Persada Press.

M. Maksum, Syaikh bin Ali. (1965).

Amsilatu Tasrifiyah. Jombang:

Maktabah Asy Syaikh Salim bin

Sa'id Nabhan.

Nawawi, Hadari, (2005). Metode

Penelitian Bidang Sosial.

Yogyakarta: Gadjah Mada Press

Hadari dan Martini Hadari. (2006). Instrumen Penelitian

Bidang Sosial. Yogyakarta:

Gadjah Mada University Press

Nadzir.Moh. (2003). Metode Penelitian.

Jakarta: PT. Ghalia Indonesia.

Nata, Abudin. (2007). Filsafat Pendidikan Islam I. Jakarta: Logos Wacana IImu

Nurhadi. (2008). Membaca Cepat dan Efektif. Bandung: Sinar Baru Algensindo.

Rusman. (2011). Model-model Pembelajaran. Jakarta: PT. Grafindo Persada.

Sanjaya, Wina (2008). Kurikulum dan

Pembelajaran. Jakarta: Kencana.

Syah, Muhibbin. (1999). Psikologi

Belajar. Jakarta: Logos. HIm

Soedarso. (1993). Sistem Membaca

Cepat dan Efektif. Jakarta:

Gramedia Pustaka Utama.

Syarifuddin, Ahmad. (2005). Mendidik

Anak Membaca, Menulis, dan

Mencintai Al-Qur'an. Jakarta:

Gema Insani.

Sardiman. (2010). Interaksi dan Motivasi Belajar Mengajar. Jakarta: Rajawali Press.

Sugiyono. (2011). Metode Penelitian Kuantitatif Kualitatif dan R\&D. Bandung: Alfabeta.

Suprijono, Agus (2011). Cooperatif Learning: Teori dan Aplikasi PAIKEM. Yogyakarta: Pustaka Pelajar.

Thohir, Muhammad Shohib. et all. (2009). Al-Qur'an dan Terjemahnya. Jakarta: Departemen Agama RI. 
Tanzeh, Ahmad, (2009). Metode Yunus, Muhammad, (1973). Kamus Penelitian Praktis. Yogyakarta: Arab Indonesia. Jakarta: Yayasan Teras. Penyelenggara

Warsono, Ahmad, (1997). Kamus Al Penterjemah/Penafsiran Al-Qur'an. Munawir. Yogyakarta: Pustaka Yunus, Mahmud, (1975). Metode Progresif. Khusus Pendidikan Agama.

Winkel, W.S. (1989). Psikologi Jakarta: Hidakaya Agung.

Pengajaran. Jakarta: PT. Zuhairini. (1983). Metode Khusus Gramedia.

Pendidikan Agama. Surabaya: Usaha Nasional. 